\title{
The Pathogenesis of Shigella Diarrhea
}

\author{
I. ENTEROTOXIN PRODUCTION BY \\ SHIGELLA DYSENTERIAE 1
}

\author{
Gerald T. Keusch, George F. Grady, Leonardo J. Mata, and \\ JAMES MCIVER \\ From the Biologic Laboratories, State Laboratory Institute, Massachusetts \\ Department of Public Health, Boston, Massachusetts 02114, and the \\ - Division of Infectious Diseases, Department of Medicine, Mount Sinai \\ School of Medicine, New York 10029
}

A B S T R A C T A strain of Shigella dysenteriae 1, freshly isolated from a patient with dysentery in Guatemala in August 1969, was found to elaborate an enterotoxin into the liquid of broth cultures. Partial purification of the enterotoxin by ultrafiltration on graded polymeric membranes and Sephadex gel filtration (Pharmacia Fine Chemicals, Inc., Piscataway, N. J.) suggested an approximate molecular weight of 55,000-60,000. The partially purified toxin was heat-labile, pronase sensitive, and activated by alkaline $\mathrm{pH}$, and it elicited fluid production in ligated rabbit ileal segments; it failed, however, to cause increased vascular permeability in skin. When the activities of equal weights of identically prepared $V$ ibrio cholerae and $S$. dysenteriae enterotoxins were compared in the rabbit ileum the latter caused a significantly smaller volume response with increased concentrations of potassium, chloride, and protein.

The previously described neurotoxic (mouse lethal) factor was also present and eluted from Sephadex G-150 with the enterotoxin. If these biological activities prove to be possessed by a single molecular species, it is suggested that it be renamed Shigella enterotoxin in recognition of the physiologically more relevant biological action.

\section{INTRODUCTION}

A protein exotoxin elaborated by Shigella dysenteriae 1 (Shiga's bacillus) has been known since 1903 (1). The

This work was presented in part at the National Meeting of the American Federation for Clinical Research, Atlantic City, 2 May 1970.

Received for publication 22 June 1971 and in revised form 19 November 1971. toxin was classified as a neurotoxin because parenteral inoculation in rabbits resulted in paralysis, cerebral and spinal cord hemorrhages, and death $(1,2)$. The protein neurotoxin was clearly distinguished from lipopolysaccharide endotoxin (LPS) ${ }^{\mathbf{1}}$ by heat lability, precipitation by trichloroacetic acid, suppression of synthesis under anaerobic conditions, and production by LPS-deficient rough strains (3-5). Van Heyningen and Gladstone obtained a highly purified preparation in 1953 (6), however with the exception of one negative study in monkeys (7), enterotoxicity was not tested by intraintestinal challenge.

The studies of Formal, LaBrec, and Schneider (8) clearly demonstrated the necessity for epithelial cell penetration and multiplication for virulence of Shigella flexneri $2 \mathrm{a}$, but did not identify the nature of the resulting bacterial-host interaction. Enterotoxin production has recently been described in several bacterial species not previously thought to be enterotoxigenic, including Escherichia coli (9), Clostridium perfringens (10), and Pseudomonas aeruginosa (11). Earlier speculation that the exotoxin of $S$. dysenteriae 1 was not truly neurotropic (12-14) made this organism the logical choice to study first among the shigellae. The occurrence of a wide spread epidemic of dysentery due to Shiga's bacillus in Central America in 1969 (15) provided the opportunity for these studies, which document that $S$. dysenteriae 1 does produce enterotoxin in vitro which is distinct and separable from endotoxin, but not to date from neurotoxin.

\footnotetext{
${ }^{1}$ Abbreviations used in this paper: $\mathrm{K}_{\mathrm{av}}$, fractional elution volume; $\mathrm{LD}_{\mathrm{so}}, 50 \%$ lethal dose; $\mathrm{LPS}$, lipopolysaccharide endotoxin; $\mathrm{PF}$, permeability altering factor.
} 


\section{METHODS}

Toxin production. A strain of $S$. dysenteriae 1, designated MK-102, was isolated at INCAP in Guatemala City from a young Guatemalan girl with dysentery in August 1969. It possessed an $\mathbf{R}$ factor for streptomycin, tetracycline, chloramphenicol, and mercuric chloride transferrable to $E$. coli K-12 (performed by Dr. David H. Smith). Culture media were prepared from $3 \%$ peptone broth (Difco Laboratories, Detroit, Mich.) fractionated by pressure dialysis through a graded polymeric membrane to retard passage of components above $10,000 \mathrm{~mol}$ wt (UM-10, Amicon Corp., Lexington, Mass.). $200 \mathrm{ml}$ of the low molecular weight dialysate were placed in 2-liter Erlenmeyer flasks and inoculated with a $\log$ phase culture. After incubation for $18 \mathrm{hr}$ at $37^{\circ} \mathrm{C}$ with vigorous aeration, organisms were removed by centrifugation at $16,300 \mathrm{~g}$ for $30 \mathrm{~min}$ (this and all subsequent operations were conducted at $4^{\circ} \mathrm{C}$ ). Final sterilization was achieved by passage through a Millipore GS membrane (Millipore Corp., Bedford, Mass.).

Fractionation procedures. The resulting product, crude Shigella enterotoxin, was concentrated by pressure dialysis through Amicon UM-10 or XM-50 membranes (molecular weight cutoff 50,000$)$. Approximately $3 \mathrm{ml}$ of the concentrate (equivalent to $1000 \mathrm{ml}$ of crude toxin) was applied to a $2.5 \times 30 \mathrm{~cm}$ column of G-150 Sephadex (Pharmacia Fine Chemicals, Piscatway, N. J.) equilibrated with $0.02 \mathrm{M}$ $\mathrm{NH}_{4} \mathrm{HCO}_{3}$. 4-ml portions were eluted and the six tubes encompassing peak enterotoxic activity were pooled and lyophilized.

Assay of biologic activity. Enterotoxic fractions were defined by titration in ligated segments of adult white New Zealand rabbit ileum as previously described (16). Active toxin solubilized in $0.1 \mathrm{M}$ phosphate buffer $(\mathrm{pH} 8)$ and inoculated into the intestinal lumen resulted in fluid accumulation causing severe distention of the loop by $12 \mathrm{hr}$ and pressure necrosis of the gut mucosa by $18 \mathrm{hr}$.

Neurotoxic activity was assayed by parenteral inoculation of the partially purified toxin in $20-\mathrm{g}$ white mice (Charles River Laboratories, Cambridge, Mass.). Deaths within 6 days of injection were tabulated and the $50 \%$ lethal dose $\left(\mathrm{LD}_{50}\right.$ ) calculated by the formulae of Reed and Muench (17).

The presence of a permeability altering factor (PF) was sought by determining the response to intradermal injection in rabbit skin as described (16). Induration of $8 \mathrm{~mm}$ diameter or more at $24 \mathrm{hr}$ was defined as a positive response. Erythema without induration was not considered a true response.

Endotoxin was assayed by the limulus amebocyte gelation test of Levin and Bang (18). Sodium and potassium concentrations were determined by flame photometry and chloride by the Cotlove electrode. Bicarbonate concentration was estimated as $[\mathrm{Na}+\mathrm{K}]-[\mathrm{Cl}]$. Protein was measured by the method of Lowry, Rosebrough, Farr, and Randall (19) uisng bovine serum albumin as standard. Data were examined statistically by Student's $t$ test.

\section{RESULTS}

Crude enterotoxin, diluted in $0.1 \mathrm{M}$ phosphate buffer $(\mathrm{pH} 8)$ and inoculated into segments of rabbit ileum resulted in gross accumulation of fluid beginning after 4-6 hr. Heated toxin $\left(90^{\circ} \mathrm{C}, 30 \mathrm{~min}\right)$ or media controls were inactive (Table I). $10 \mu \mathrm{l}$ of the crude toxin
TABLE I

Effect of Crude Shigella Enterotoxin on Fluid Production by Ligated Rabbit Ileal Segments

\begin{tabular}{lcc}
\hline \multicolumn{1}{c}{ Preparation } & No. of tests & Fluid produced \\
\hline & & $\mathrm{ml} / \mathrm{cm}$ \\
Active toxin* & 42 & $1.8 \pm 0.2 \ddagger$ \\
Heated toxin $\left(90^{\circ} \mathrm{C}, 30 \mathrm{~min}\right)$ & 9 & $0.3 \pm 0.1$ \\
Uninoculated medium & 13 & $0.1 \pm 0.1$ \\
\hline
\end{tabular}

* $1 \mathrm{ml}$ of crude culture filtrate per $7 \mathrm{~cm}$ loop of rabbit ileum. $\ddagger \pm 1$ sEM.

suspended in 1-2 $\mathrm{ml}$ of phosphate buffer usually produced a maximum fluid response.

Fractionation of toxin and estimation of molecular weight. Simultaneous titration of enterotoxin activity of the filtrate and retentate obtained by membrane ultrafiltration allowed a preliminary estimation of molecular weight. Over $99 \%$ of the enterotoxicity was retained by the UM-10 membrane, while approximately $90 \%$ was present in the retentate from the XM-50 membrane. These data suggested a molecular weight somewhat in excess of 50,000 .

Chromatography on a calibrated (16) Sephadex G150 column supported this estimate. Three fractions were discernible (Fig. 1). Fraction A eluted at the void volume of the column and was distinctly opalescent. Previous experience with cholera enterotoxin indicated that anthrone-positive saccharide, presumably reflecting LPS, would be found principally in the fraction first eluted (16). In the current studies of shigella enterotoxin, LPS activity measured directly by the limulus assay was found to coincide with peak opalescence in fraction A (Table II). This material was essentially devoid of enterotoxicity (Fig. 1, middle panel). Rather, peak ileal loop reactive toxin was contained in fraction $\mathrm{B}$, eluting at a fractional elution volume $\left(\mathrm{K}_{\mathrm{av}}\right)$ of 0.45 0.5 , corresponding to a molecular weight of $55-60,000$ (16). When crude toxin was washed with 3 vol of buffer through the Amicon XM-50 membrane before chromatography a sharper peak was obtained (Fig. 1, upper panel, solid line) although $50 \%$ of the toxin yield was thereby sacrified. Approximately $40 \%$ of the enterotoxin activity trailed into fraction $\mathrm{C}$, a yellow-brown material also containing lower molecular weight media components. LPS activity did not parallel enterotoxicity; LPS per milligram dry weight in fraction $B$ was less than $10 \%$ of that found in fraction A, while less than $1 \%$ was present in fraction C (Table II).

Properties of shigella enterotoxin. Consistently positive ileal loops were obtained with $0.5 \mu \mathrm{g}$ of lyophilized fraction B; this material, partially purified Shigella enterotoxin (G-150 enterotoxin) was used for further study. 


\section{SHIGA (MK-102) TOXIN}
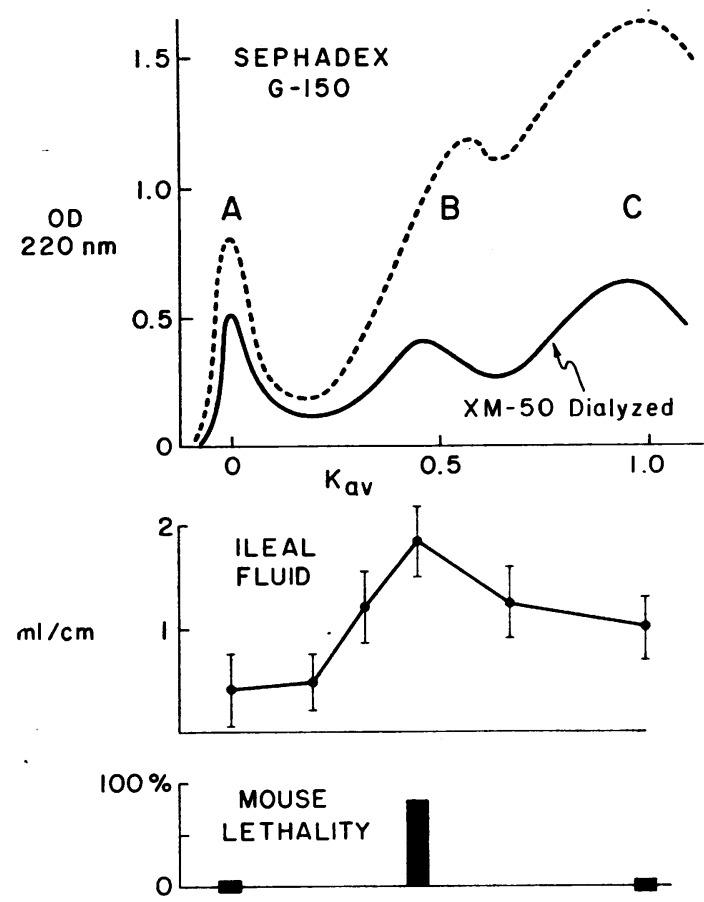

FIGURE 1 Upper panel: elution of Shigella enterotoxin from Sephadex G-150 without (dotted line) and with (solid line) prior diafiltration on an Amicon XM-50 membrane. Middle panel: fluid response of ligated rabbit ileal segments to various toxin fractions. Lower panel : assay of neurotoxin activity of the three major peaks obtained from Sephadex chromatography.

The effect of varying buffer $\mathrm{pH}$ on toxin induced ileal fluid accumulation is shown in Table III. Enterotoxicity was potentiated at alkaline $\mathrm{pH}$ and inhibited by acid conditions. While fluid production at $\mathrm{pH} 10$ was increased over that at $\mathrm{pH} 8$ at threshold doses of

TABLE II

Endotoxin Activity (Limulus Lysate Gelation) in S. Dysenteriae 1 Culture Filtrate Chromatographed on Sephadex G-150

\begin{tabular}{|c|c|c|c|c|c|}
\hline \multirow[b]{3}{*}{ Weight } & \multicolumn{5}{|c|}{ Preparation tested } \\
\hline & \multicolumn{3}{|c|}{ S. dysenteriae 1 filtrate } & \multicolumn{2}{|c|}{ Endotoxin } \\
\hline & Peak A & Peak B & Peak C & S. flexneri* & E. coli \\
\hline$\mu g$ & & & & & \\
\hline 10 & $+\ddagger$ & + & + & + & + \\
\hline 1 & + & + & - & + & + \\
\hline 0.1 & + & - & - & + & + \\
\hline 0.01 & \pm & - & - & + & + \\
\hline
\end{tabular}

* Difco Laboratories, Detroit, Mich.

$\ddagger+=$ Gelation within $30 \mathrm{~min}$ at $37^{\circ} \mathrm{C}$.
TABLE III

Effect of Varying Buffer $p H$ on G-150 Shigella Enterotoxin Activity

\begin{tabular}{|c|c|c|c|}
\hline \multirow[b]{2}{*}{ Toxin dose } & \multicolumn{3}{|c|}{ Ileal loop fluid, buffer pH } \\
\hline & 6 & 8 & 10 \\
\hline$\mu g$ & $\mathrm{ml} / \mathrm{cm}$ & $\mathrm{ml} / \mathrm{cm}$ & $\mathrm{ml} / \mathrm{cm}$ \\
\hline 0 (control) & $\mathrm{ND}^{*}$ & $0.3 \pm 0.2 \ddagger(10) \S$ & $0.5 \pm 0.2(11)$ \\
\hline 0.5 & $0.1 \pm 0.1$ & $1.0 \pm 0.3$ & $1.6 \pm 0.4$ \\
\hline 5.0 & $1.6 \pm 0.5(6)$ & $2.4 \pm 0.2$ & $2.4 \pm 0.2$ \\
\hline
\end{tabular}

* Not done.

$\ddagger \pm 1$ SEM.

$\$$ Number of segments inoculated.

toxin, this was offset somewhat by more frequent occurrence of "nonspecific" positive loops. At a challenge dose of $5 \mu \mathrm{g}$, toxin in $\mathrm{pH} 8$ buffer resulted in a maximum response, thus obscuring the increased sensitivity of the higher $\mathrm{pH}$. Optimum conditions were defined on the basis of these data and toxin was solubilized as noted in $0.1 \mathrm{~m}$ phosphate, $\mathrm{pH} .8$ for all other studies.

Heat lability of G-150 enterotoxin was determined by assay of control and heated toxin preparations in 10 rabbits (Table IV). Partial inactivation was achieved at $60^{\circ} \mathrm{C}$ for $30 \mathrm{~min}$, and approximately $90 \%$ inactivation at $90^{\circ} \mathrm{C}$ for $10 \mathrm{~min}$. Virtually complete loss of enterotoxicity was obtained by heating at $90^{\circ} \mathrm{C}$ for 30 $\min$.

The effect of proteolytic enzymes on biologic activity of the enterotoxin was studied using the mouse lethality (neurotoxin) assay. Incubation of $250 \mu \mathrm{g}$ of toxin in $0.05 \mathrm{M}$ PO buffer ( $\mathrm{pH} 7.5$ ) with $20 \mu \mathrm{g}$ of pronase (Streptomyces griseus protease, Grade B, Calbiochem, Los Angeles, Calif.) for $5 \mathrm{hr}$ at $37^{\circ} \mathrm{C}$ before i.v. inoculation into mice completely destroyed toxicity (Table V). Similar incubation with $40 \mu \mathrm{g}$ trypsin (2x crystalized, salt-free trypsin, Worthington Biochemical Corp., Freehold, N. J.) failed to reduce mouse mortality. Trypsin or pronase alone did not affect the results. Attempts to demonstrate pronase lability of

TABLE IV

Heat Lability of G-150 Shigella Enterotoxin

\begin{tabular}{lc}
\hline Heat treatment & neal fluid accumulation \\
\hline & \multicolumn{1}{c}{$m^{i} / \mathrm{cm}$} \\
None (control) & $2.3 \pm 0.1^{*}(16) \ddagger$ \\
$60^{\circ} \mathrm{C} / 10 \mathrm{~min}$ & $2.4 \pm 0.2 \quad(8)$ \\
$60^{\circ} \mathrm{C} / 30 \mathrm{~min}$ & $1.8 \pm 0.3(16)$ \\
$90^{\circ} \mathrm{C} / 10 \mathrm{~min}$ & $1.1 \pm 0.3(16)$ \\
$90^{\circ} \mathrm{C} / 30 \mathrm{~min}$ & $0.1 \pm 0.2 \quad(8)$ \\
\hline
\end{tabular}

$* 1$ SEM.

$\ddagger$ Number of segments tested. 
TABLE V

Effect of Pretreatment with Proteolytic Enzymes on Biologic Activity of S. dysenteriae 1 Enterotoxin in Mice

\begin{tabular}{lcc}
\hline Treatment & Toxin dose & Mouse lethality \\
\hline & & $\%$ mortality \\
None & $50 \mu \mathrm{g}$ & 40 \\
None & $125 \mu \mathrm{g}$ & 80 \\
None & $250 \mu \mathrm{g}$ & 100 \\
Trypsin & None & 0 \\
Trypsin & $250 \mu \mathrm{g}$ & 100 \\
Pronase & None & 0 \\
Pronase & $250 \mu \mathrm{g}$ & 0 \\
\hline
\end{tabular}

enterotoxin activity in the ileal loop, however, were inconclusive because the enzyme itself resulted in frequent positive loops.

The volume and composition of the evoked fluid were serially determined in another group of rabbits (Table VI). For the purpose of comparison, separate loops in each animal were inoculated with equivalent weights of lyophilized toxins similarly prepared and purified from $V$. cholerae or $S$. dysenteriae 1 . Fluid composition was similar when 5 or $50 \mu \mathrm{g}$ of toxin was inoculated, and these data have been pooled for this analysis. A marked increase in volume response of the intestinal mucosa to Shigella toxin was noted as the terminal ileum was approached. In some animals there was as much as a 100 -fold change in threshold response over a span of $50-60 \mathrm{~cm}$ of intestine. The volume response to cholera toxin was significantly greater $(P<0.05)$ at 12 and $18 \mathrm{hr}$ than that evoked by Shigella toxin (Table VI; Fig. 2). $\mathrm{Na}$ and $\mathrm{K}$ concentrations did not vary with time, whereas chloride steady rose (as $\mathrm{HCO}_{3}$ and other anions presumably fell). The fluid response to Shigella toxin contained higher concentrations of $\mathrm{K}$ and $\mathrm{Cl}$ than found in response to cholera toxin $(\dot{P}<0.05)$. Protein concentration in response to the latter remained characteristically low for the first $12 \mathrm{hr}$. In contrast, increased protein content in loops challenged with Shigella toxin was evident at $6 \mathrm{hr}$ and reached statistical significance $(P<0.01)$ at $12 \mathrm{hr}$. Even after $18 \mathrm{hr}$, when the integrity of the mucosa was markedly altered, the protein concentration of the loop fluid remained well within the range of a transudate.

Other biologic activity. Neurotoxin activity was assayed in each of the three fractions obtained from Sephadex G-150 chromatography (Fig. 1, bottom panel) and it aligned with peak enterotoxin activity in frac-

TABLE VI

Composition and Volume of the Fluid Evoked by G-150 Shigella and Cholera Toxins

\begin{tabular}{|c|c|c|c|c|c|}
\hline \multirow[b]{2}{*}{ Determination } & \multirow[b]{2}{*}{ Toxin } & \multicolumn{3}{|c|}{ Time } & \multirow[b]{2}{*}{ All values } \\
\hline & & $6 \mathrm{hr}$ & $12 \mathrm{hr}$ & $18 \mathrm{hr}$ & \\
\hline Volume, $\mathrm{ml} / \mathrm{cm}$ & $\begin{array}{l}\text { Shigella } \\
\text { Cholera }\end{array}$ & $\begin{array}{c}0.8 \pm 0.1^{*} \\
(\mathrm{NS}) \ddagger \\
1.0 \pm 0.1\end{array}$ & $\begin{array}{c}1.0 \pm 0.2 \\
(<0.05) \\
1.6 \pm 0.2\end{array}$ & $\begin{array}{c}1.8 \pm 0.2 \\
(<0.02) \\
2.7 \pm 0.3\end{array}$ & $\begin{array}{c}1.2 \pm 0.2 \\
(<0.05) \\
1.8 \pm 0.2\end{array}$ \\
\hline \multirow[t]{2}{*}{$\mathrm{Na}^{+}, m E q /$ liter } & Shigella & $\begin{array}{c}150 \underset{ }{ \pm 3} \\
(\mathrm{NS})\end{array}$ & $\begin{array}{c}153 \underset{\text { (NS) }}{ \pm 3} \\
\text { (NS }\end{array}$ & $\begin{array}{c}154 \underset{(\mathrm{NS})}{ \pm 1} \\
\end{array}$ & $\begin{array}{c}152 \pm 2 \\
(\mathrm{NS})\end{array}$ \\
\hline & Cholera & $154 \pm 3$ & $155 \pm 2$ & $152 \pm 1$ & $154 \pm 2$ \\
\hline $\mathrm{K}^{+}, m E q /$ liter & $\begin{array}{l}\text { Shigella } \\
\text { Cholera }\end{array}$ & $\begin{array}{c}5.0 \pm 0.2 \\
(\mathrm{NS}) \\
4.7 \pm 0.2\end{array}$ & $\begin{array}{c}5.4 \pm 0.7 \\
(<0.05) \\
4.6 \pm 0.1\end{array}$ & $\begin{array}{l}5.1 \pm 0.3 \\
(<0.05) \\
4.5 \pm 0.1\end{array}$ & $\begin{array}{c}5.2 \pm 0.3 \\
(<0.05) \\
4.6 \pm 0.1\end{array}$ \\
\hline \multirow[t]{2}{*}{$\mathrm{Cl}^{-}, m E q /$ liter } & Shigella & $\begin{array}{c}65 \pm 5 \\
(P<0.02)\end{array}$ & $\begin{array}{c}75 \pm 2 \\
(P<0.05)\end{array}$ & $\begin{array}{c}86 \pm 4 \\
\text { (NS) }\end{array}$ & $\begin{array}{l}72 \pm 3 \\
(<0.05)\end{array}$ \\
\hline & Cholera & $48 \pm 2$ & $64 \pm 2$ & $79 \pm 4$ & $65 \pm 2$ \\
\hline $\mathrm{HCO}_{3}-\S, m E q /$ liter & $\begin{array}{l}\text { Shigella } \\
\text { Cholera }\end{array}$ & $\begin{array}{r}90 \\
111\end{array}$ & $\begin{array}{l}83 \\
96\end{array}$ & $\begin{array}{l}73 \\
77\end{array}$ & $\begin{array}{l}85 \\
94\end{array}$ \\
\hline \multirow[t]{2}{*}{ Protein, $m g / 100 m l$} & Shigella & $\begin{array}{c}225 \underset{(\mathrm{NS})}{ \pm 52} \\
\text { t5 }\end{array}$ & $\begin{array}{c}363 \pm 61 \\
(<0.01)\end{array}$ & $\begin{array}{r}495 \pm 46 \\
(<0.01)\end{array}$ & $\begin{array}{c}388 \pm 36 \\
(<0.01)\end{array}$ \\
\hline & Cholera & $142 \pm 29$ & $170 \pm 41$ & $242 \pm 29 \|$ & $171 \pm 24$ \\
\hline
\end{tabular}

* Mean \pm 1 SEM of 6-12 determinations.

$\ddagger P$ value; $\mathrm{NS}=$ not significant at the $P=0.05$ level.

\& Calculated as $\left(\mathrm{Na}^{+}+\mathrm{K}^{+}\right)-\left(\mathrm{Cl}^{-}\right)$.

$\|$ Three determinations only. 

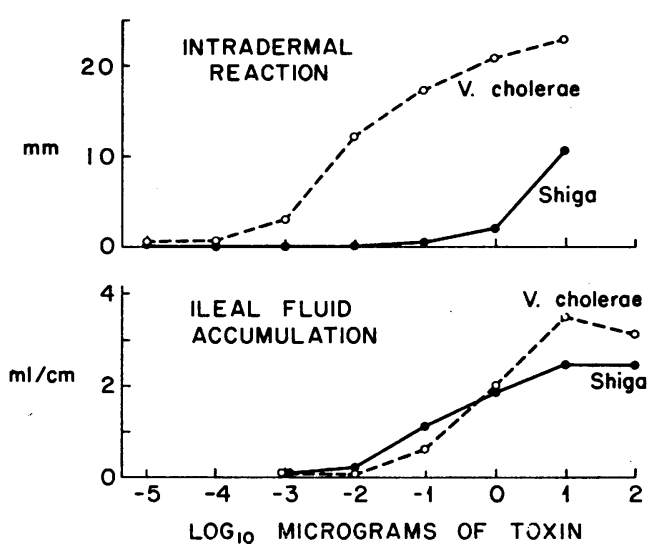

FIGURE 2 Simultaneous titration of identically purified enterotoxins from $V$. cholerae and $S$. Shiga. Upper panel: assay for permeability factor in rabbit skin (millimeters of palpable induration at $24 \mathrm{hr}$ ). Lower panel : enterotoxin activity assayed in ligated rabbit ileal segments.

tion $\mathrm{B}$ and was similarly destroyed by heating at $90^{\circ} \mathrm{C}$ for $30 \mathrm{~min}$. When fractions $\mathrm{B}$ and $\mathrm{C}$ were simultaneously titrated to determined the i.v. LDso the results paralleled their content of enterotoxic activity. The $\mathrm{LD}_{\mathrm{so}}$ for fraction B was $68 \mu \mathrm{g}$, and for fraction C, $85 \mu \mathrm{g}$. On an absolute weight basis over 100 times more lyophilized toxin was required to kill a $20 \mathrm{~g}$ mouse than to induce fluid accumulation in a $7 \mathrm{~cm}$ ileal segment in the rabbit.

PF activity was not detected in the crude enterotoxin preparation. Similarly purified shigella and cholera toxins were then tested simultaneously in the skin of the same rabbit (Fig. 2). Although both toxins exhibited a comparable threshold response in the ileum, Shigella toxin contained $1 / 1000$ as much PF activity. In contrast to cholera toxin, measurable induration occurred only at very high doses of Shigella toxin, at which levels heated toxin also resulted in marginal skin responses.

\section{DISCUSSION}

The present study demonstrates that we may now add Shigella dysenteriae 1 to the list of enterotoxin-producing bacteria. There has hardly been a pressing need to postulate the existence of such an enterotoxin because virulence of Shigella species has been clearly linked to mucosal penetration and intraepithelial multiplication (8). Moreover, attempts by others to find enterotoxin production by $S$. dysenteriae 1 (7) or $S$. flexneri 2a (20) had been uniformly unsuccessful. Arm, Floyd, Faber, and Hayes (20) suggested that diffusible cell-free products of Shigellae might play a role in the production of diarrhea (20). Their hypothesis was based on two observations: that living organisms were required for a positive response in ligated rabbit ileal segments, and the fact that inflammation of the bowel wall and accumulation of fluid in the lumen occurred in advance of significant bacterial proliferation. Takeuchi, Sprinz, La Brec, and Formal (21) reported a similar sequence following peroral challenge with living, virulent Shigellae in the opium treated guinea pig. At $8 \mathrm{hr}$ after infection ileitis was present while only an occasional intraepithelial bacillus was found. By $24 \mathrm{hr}$, however, many invading bacilli were found, both by conventional histological and fluorescent antibody staining techniques. Degenerative changes were also noted in epithelial cells irrespective of the presence or absence of penetrating bacteria.

Whether enterotoxin is produced by all Shigella species or has a pathophysiological role in shigellosis is not clear at present. Proof of this hypothesis would not invalidate the current notions of the importance of epithelial penetration for virulence. The small bowel is rapidly cleared of bacteria by peristalsis (22), and avirulent nonpenetrating Shigella mutants quickly disappear (23). When this is prevented by ligation of the terminal ileum the in vivo growth curve of the mutant parallels that of the virulent strain (23). Epithelial penetration could, therefore, be seen as protecting the organism from the efficient clearance mechanisms of the bowel and thereby allowing establishment of propagating infection. Diarrhea would then follow subsequent in vivo enterotoxin production.

Because shigellosis is commonly termed bacillary dysentery and equated with colitis, one might question the clinical relevance of a toxin active in the small bowel. While the classical dysentery syndrome does include bloody mucoid stools and tenesmus related to large bowel involvement (22), the majority of humans with clinically manifest shigellosis develop only watery diarrhea $(24,25)$, which is usually considered a small bowel syndrome (22). In the monkey, the only natural host for Shigella other than man, colitis is the major manifestation of infection, although ileitis does occur in some of the animals (26). Ileitis is a prominent feature of laboratory infection of guinea pigs (21), and an acute small intestinal form has been described in man (27). In both naturally and laboratory acquired shigellosis, watery diarrhea precedes dysentery by 1-2 days. During this period of the induced laboratory disease with $S$. flexneri 2a, organisms in high concentration can be isolated from the small bowel fluids (H. L. Dupont, M.D., personal communication). The bacterial counts diminish in the ileum as colitis occurs and symptoms of dysentery become prominent. Thus the clinical manifestations of disease follow the progression of infection from distal small bowel to large intestine, and therefore appear dependent on duration of the infection. An identical progression has been noted in the guinea pig model $(21,28)$. The possible 
role of enterotoxin in the colonic phase of shigellosis is open to speculation. Other enterotoxins are known to affect the large bowel. Severe colitis can result from large doses of staphylococcal enterotoxin (29). Prohaska and colleagues have suggested that pseudomembraneous enterocolitis due to the staphylococcus is a toxin-mediated disease $(29,30)$. Even cholera toxin, primarily active in the small bowel, has been reported to exert a measurable effect on the colon (31).

The current studies do not allow conclusions on the possible identity of $S$. dysenteriae 1 enterotoxin with the previously demonstrated Shiga neurotoxin. The latter has usually been isolated from bacterial autolysates (1) or extracted from the intact cells (6) whereas our preparation was isolated from cell-free growth medium. However the distinction is not clear because some autolysis is to be expected after $18 \mathrm{hr}$ of incubation as indicated by the endotoxic fraction $\mathrm{A}$ demonstrated by Sephadex chromatography. Exotoxins may be present within the cells (where they have been referred to as protein endotoxins) as well as excreted into the extracellular medium (32). The highly purified neurotoxin produced by van Heyningen and Gladstone (6) contained $750 \mathrm{LD}$ so $/ \mathrm{mg}$ (per kilogram mouse) whereas the material we isolated from a single passage through Sephadex G-150 contained only 12.5 mouse $\mathrm{LD}_{\mathrm{so}} / \mathrm{mg}$. The latter figure is almost identical to that for the neurotoxic dialyzed autolysate from a culture of a rough strain of $S$. dysenteriae 1 studied by Howard (13). In the studies of Branham, Dack, and Riggs no effect was noted when 10,000-20,000 monkey i.v. $L D_{50}$ doses of neurotoxin were inoculated intraluminally in isolated pouches of monkey small and large bowel (7). Several explanations are possible to account for this observation: a species difference in sensitivity of the gut to the toxin between monkey and rabbit, differential lability of enterotoxicity and neurotoxicity under the conditions of production utilized, or a lack of identity of neurotoxin and enterotoxin. We cannot resolve this question, but it is of interest that the strains of $S$. dysenteriae 1 utilized in Branham's study also failed to cause diarrheal disease when fed in enormous numbers to the monkeys.

The possible distinction between enterotoxin and neurotoxin is further blurred by the recent observation that purified cholera enterotoxin like Shigella neurotoxin kills mice when given i.v. (33). Since all manifestations of cholera are considered to be secondary to intestinal fluid loss (34), mouse lethality appears to be a laboratory phenomenon. This may also pertain to shigellosis since there has never been clinical evidence in man to suggest any particular nervous system involvement in disease due to the neurotoxin-producing Shiga bacillus. Central nervous system manifestations occur with equal frequency during infection with all
Shigella species (35) and were, in fact, strikingly absent in the recent $S$. dysenteriae 1 epidemic (15). If Shiga enterotoxin is neurotoxin rediscovered, that is, a single exotoxin with two biological activities, it may be justified on physiological grounds to break historical tradition and reclassify it as an enterotoxin.

\section{ACKNOWLEDGMENTS}

Dr. Eugene Ainbender performed the limulus assay for endotoxin.

This work was initiated while one of us (Dr. Keusch) was a participant in the Summer Course in Public Health Nutrition supported by the Institute of Nutrition of Central America and Panama (INCAP), Guatemala, Central America.

This work was supported by the U. S. Army Research and Development Command under research contracts DA 49-139-MD2707 and DADA-17-71 C-1042.

\section{REFERENCES}

1. Conradi, H. 1903. Ueber lösliche durch aseptische autolyse erhaltene Giftstoffe von Ruhr-und Typhusbazillen. Deut. Med. Wochenschr. 29 : 26.

2. Flexner, S., and J. E. Sweet. 1906. The pathogenesis of experimental colitis and the relation of colitis in animal and man. J. Exp. Med. 8: 514.

3. Olitsky, P. K., and I. J. Kligler. 1920. Toxins and antitoxins of Bacillus dysenteriae Shiga. J. Exp. Med. $31: 19$.

4. McCartney, J. E., and P. K. Olitsky. 1923. Separation of the toxins of Bacillus dysenteriae Shiga. J. Exp. Med. 37 : 767.

5. Boivin, A., and L. Mesrobeanu. 1937. Recherches sur les toxines du bacille dysenterique. Sur la signification des toxines produites par la bacille de Shiga et par le bacille de Flexner. Compt. Rend. Soc. Biol. 126: 652.

6. Van Heyningen, W. E., and G. P. Gladstone. 1953. The neurotoxin of Shigella shigae. 1. Production, purification and properties of the toxin. Brit. J. Exp. Pathol. $34: 202$.

7. Branham, S. E., G. M. Dack, and D. B. Riggs. 1953. Studies with Shigella dysenteriae (Shiga). IV. Immunological reactions in monkeys to the toxins in isolated intestinal pouches. J. Immunol. 70: 103.

8. Formal, S. B., E. H. La Brec, and H. Schneider. 1965. Pathogenesis of bacillary dysentery in laboratory animals. Fed. Proc. 24 : 29.

9. Smith, H. W., and S. Halls. 1967. Studies on Escherichia coli enterotoxin. J. Pathol. Bacteriol. 93: 531.

10. Duncan, C. L., and D. H. Strong. Ileal loop fluid accumulation and production of diarrhea in rabbits by cell-free products of Clostridium perfringens. J. Bacteriol. $100: 86$.

11. Kubota, Y.. and P. V. Liu. 1970. An enterotoxin of Pseudomonas aeruginosa. J. Infect. Dis. 123: 97.

12. Bridgwater, F. A. J., R. S. Morgan, K. E. K. Rowson, and G. P. Wright. 1955. The neurotoxin of Shigella shigae. Morphological and functional lesions produced in the central nervous system of rabbits. Brit. J. Exp. Pathol. 36 : 447.

13. Howard, J. G. 1955. Observations on the intoxication produced in mice and rabbits by the neurotoxin of Shigella shigae. Brit. J. Exp. Pathol. 36: 439.

Pathogenesis of Shigella Diarrhea 
14. Cavanagh, J. B., J. G. Howard, and J. L. White. 1956. The neurotoxin of Shigella shigae. A comparative study of the effects produced in various laboratory animals. Brit. J. Exp. Pathol. 37 : 272.

15. Mata, L. J., E. J. Gangarosa, A. Caceres, D. R. Perera, and M. L. Mejicanos. 1970. Epidemic Shiga bacillus dysentery in Central America. I. Etiologic investigations in Guatemala, 1969. J. Infect. Dis. 122: 170.

16. Duhamel, R. C., P. Talbot, and G. F. Grady. 1970. Production, purification, and assay of cholera enterotoxin. J. Infect. Dis. 121: S85.

17. Reed, L. J., and H. Muench. 1938. A simple method of estimating fifty percent endpoints. Amer. J. Hyg. 27 : 493.

18. Levin, J., and F. B. Bang. 1968. Clottable protein in limulus: its localization and kinetics of its coagulation by endotoxin. Thromb. Diath. Haemorrh. 19: 186.

19. Lowry, O. H., N. J. Rosebrough, R. J. Farr, and R. J. Randall. 1951. Protein measurement with the Folin phenol reagent. J. Biol. Chem. 193: 265.

20. Arm, H. G., T. M. Floyd, J. E. Faber, and J. R. Hayes. 1965. Use of ligated segments of rabbit small intestine in experimental shigellosis. J. Bacteriol. 89: 803.

21. Takeuchi, A., H. Sprinz, E. H. La Brec, and S. B. Formal. 1965. Experimental bacillary dystentery. An electron microscopic study of the response of the intestinal mucosa to bacterial invasion. Amer. J. Pathol. 47:1011.

22. Grady, G. F., and G. T. Keusch. 1971. Pathogenesis of bacterial diarrheas. N. Engl. J. Med. 285: 831-841, 891900 .

23. La Brec, E. H., H. Schneider, T. J. Magnani, and S. B. Formal. 1964. Epithelial cell penetration as an essential step in the pathogenesis of bacillary dysentery. $J$. Bacteriol. 88 : 1503.

24. Hardy, A. V., and J. Watt. 1945. Studies of the acute diarrheal diseases. XIV. Clinical observations. $P u b$. Health. Rep. 60: 521 .
25. Dupont, H. L., R. B. Hornick, A. T. Dawkins, M. J. Snyder, and S. B. Formal. 1969. The response of man to virulent Shigella flexneri 2a. J. Infect. Dis. 119: 296.

26. Formal, S. B., T. H. Kent, S. Austin, and E. H. La Brec. 1966. Fluorescent-antibody and histological study of vaccinated and control monkeys challenged with Shigella flexneri. J. Bacteriol. 91: 2368.

27. Manson-Bahr, P. H. 1966. Mansons Tropical Diseases. Bailliere, Tindall and Cassell Ltd., London. 16th edition. 406.

28. Formal, S. B., G. J. Dammin, E. H. La Brec, and $\mathrm{H}$. Schneider. 1958. Experimental Shigella infections: characteristics of a fatal infection produced in guinea pigs. J. Bacteriol. 75 : 604.

29. Tan, T. L., C. T. Drake, M. J. Jacobson, and J. V. Prohaska. 1959. The experimental development of pseudomembranous enterocolitis. Surg. Gynecol. Obstet. 108: 415.

30. Prohaska, J. V., E. T. Long, and T. S. Nelson. 1956. Pseudomembranous enterocolitis; its etiology and the mechanism of the disease process. Arch. Surg. 72: 977.

31. Swallow, J. F., C. F. Code, and R. Freter. 1968. Effect of cholera toxin on water and ion fluxes in the canine bowel. Gastroenterology. $54: 35$.

32. Raynaud, M., and J. E. Alouf. 1970. Intracellular versus extracellular toxins. In Microbial Toxins. S. J. Ajl S. Kadis, and T. C. Montie, editors. Academic Press, Inc., New York. 1: 67.

33. Watanabe, Y. cited by R. A. Finkelstein. 1970. In Workshop on the Immunology of Cholera, 25-26 Sept. 1969. J. Infect. Dis. 121: S114.

34. Watten, R. H., F. M. Morgan, V. N. Songkhla, B Vanikiati, and R. A. Phillips. 1959. Water and electrolyte studies in cholera. J. Clin. Invest. 38: 1879.

35. Barrett-Connor, E., and J. D. Conner. 1970. Extraintestinal manifestations of shigellosis. Amer. J. Gastroenterol. 53 : 234 